\title{
Katsauksia
}
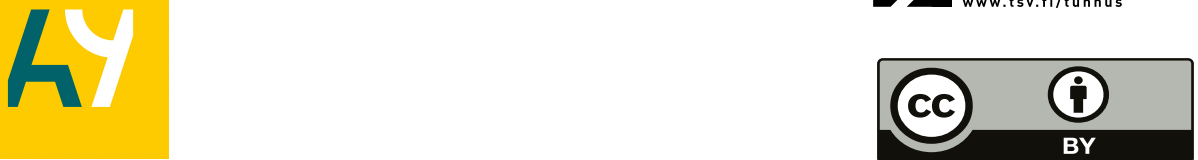

Riikka Puhakkaa, Mira Grönroos ${ }^{b}$, Marja Roslundc, Anirudra Parajulid, Mika Saarenpääe, Laura Soininenf, Aki Sinkkoneng

\section{Luontopohjaisia ratkaisuja immuunijärjestelmän häiriöihin}

Nykykäsityksen mukaan ihmisen puolustusjärjestelmä tarvitsee luonnon monimuotoisia mikrobeja pysyäkseen terveenä. Kaupungistuneissa yhteiskunnissa luontoalueet ovat kaventuneet ja ihmisten luontokontaktit vähentyneet, minkä vuoksi tarvitaan innovatiivisia luontopohjaisia ratkaisuja luontokosketuksen säilyttämiseksi ja immuunijärjestelmän häiriöiden ehkäisemiseksi.

\section{Johdanto}

Luontopohjaisten ratkaisujen avulla pyritään saavuttamaan samanaikaisia hyötyjä niin ympäristölle, terveydelle kuin taloudelle. Terveyteen ja hyvinvointiin liittyvät näkökulmat ovat viime vuosina nousseet entistä näkyvämmiksi suomalaisessa luonnonvara- ja ympäristöpolitiikassa. Luonnosta saatavia aineettomia hyötyjä on nostettu aineellisten hyötyjen rinnalle - esimerkiksi korostamalla luontomatkailun ja luontolähtöisen hyvinvointimatkailun kasvumahdollisuuksia (esim. Konu ym. 2017). Luonto pyritään yhä useammin liittämään myös osaksi sosiaali-, terveys-, kasvatus- ja kuntoutuspalveluja (esim. Jäppinen ym. 2014; Haahtela ym. 2017). Yhteiskunnassa on alettu korostaa luonnon terveys- ja hyvinvointihyötyjä voimakkaammin samalla kun aihepiiriä koskeva tutkimus on lisääntynyt. Tutkimuksissa on saatu näyttöä luontokontaktin hyödyistä niin ihmisen fyysiselle, psyykkiselle kuin sosiaaliselle hyvinvoinnille. Luonnon on todettu esimerkiksi parantavan mielialaa, elvyttävän stressistä sekä lisäävän tarkkaavaisuutta ja keskittymiskykyä (ks. Keniger ym. 2013; Aerts ym. 2018).

Minna Santaoja pohti Alue ja Ympäristö -lehdessä (2018) julkaistussa puheenvuorossaan ruoka-allergioiden syntyä ja nosti esille, että viimeaikainen tutkimustieto luonnon terveyshyödyistä on entisestään vahvistanut käsitystä ihmisen ja luonnon keskinäisriippuvuudesta. Jatkamme keskustelua tässä katsauksessa esittelemällä uusimpia seuranta- ja altistustutkimusten tuloksia sekä pohtimalla, millaisin keinoin ihmisen terveyttä voitaisiin edistää kaupunkiympäristössä.

Suomalaistutkijoiden esittämän biodiversiteettihypoteesin mukaan hygieniatason nousu ja ympäristön biologisen monimuotoisuuden kaventuminen ovat vähentäneet immuunijärjestelmän luonnollista kehitystä edistävää altistusta mikrobeille. Tämä on johtanut ihmisen elimistön mikrobiston epätasapainoon, immuunijärjestelmän häiriöihin

${ }^{a}$ Ekosysteemit ja ympäristö -tutkimusohjelma, Bio- ja ympäristötieteellinen tiedekunta, Helsingin yliopisto, riikka.puhakka@helsinki.fi

b, c, d, e, f, g Ekosysteemit ja ympäristö -tutkimusohjelma, Bio- ja ympäristötieteellinen tiedekunta, Helsingin yliopisto 
ja kroonisiin tulehdussairauksiin (von Hertzen ym. 2011; Hanski ym. 2012; Ruokolainen ym. 2016; Haahtela 2019). Yhteiskunnan kaupungistuessa ja luontokontaktien vähentyessä seurauksena on ollut immuunijärjestelmän vakavien häiriöiden kuten allergioiden, astman ja tyypin 1 diabeteksen voimakas lisääntyminen (esim. Haahtela ym. 2013). Joka viidennen kehittyneiden maiden asukkaan on arvioitu kärsivän immuunivälitteisistä sairauksista. Viime aikoina tutkimuksissa on nostettu esille myös suoliston mikrobiston merkitys ihmisen henkiselle hyvinvoinnille (Rieder ym. 2017).

Nykyisen tutkimustiedon valossa laaja ja monipuolinen mikrobialtistus suojaa ihmistä monilta immuuni- ja autoimmuunisairauksilta. Erityisen tärkeänä pidetään kosketusta metsien ja maatalousalueiden monipuoliseen mikrobi- ja pieneliöyhteisöön. Ennen toista maailmansotaa luonnollista mikrobiomia oli elinympäristössä siinä määrin, että ihmisen immuunipuolustusjärjestelmä seuloi sitä vaarallisten mikrobien löytämiseksi ja tuhoamiseksi. Nykyisin kaupungistuneissa yhteiskunnissa immuunipuolustus kohtaa yhä vähemmän ympäristön luonnollisia mikrobeja. Siten immuunipuolustus voi alkaa seuloa ja tunnistaa vaarallisiksi ihmisen omia soluja, elimistön toiminnan kannalta välttämättömiä mikrobeja tai harmittomia pienhiukkasia, kuten siitepölyä ja ruuan allergeeneja (esim. Ege ym. 2012; Rook 2013; Ruokolainen ym. 2015). Allergioiden ja muiden immuunivälitteisten sairauksien riskiä näyttää lisäävän muun muassa antibioottien käyttö, joka tuhoaa elimistöstä paitsi taudinaiheuttajat myös runsaasti harmittomia bakteereita (ks. Haahtela ym. 2013). Lisäksi kaupungeissa esiintyvät haitta-aineet, kuten liikenteen pakokaasut, voivat muuntaa elinympäristön (Parajuli ym. 2017; Roslund ym. 2018) ja elimistön (Roslund ym. 2019) mikrobiyhteisöä sekä immuunipuolustuksen toimintaa.

Uudenlainen strategia allergisten sairauksien vähentämiseksi on konkretisoitunut esimerkiksi Kansallisessa allergiaohjelmassa (2008-2018), jossa on saatu hyviä tuloksia kääntämällä välttämisstrategia sietostrategiaksi ja nostamalla immuunitoleranssi keskiöön (Haahtela ym. 2015).

\section{Mikrobialtistuksen hyödyt}

Helsingin ja Tampereen yliopistojen monitieteisessä, Business Finlandin rahoittamassa ADELE-hankkeessa ja sen sisarhankkeissa (ImmunoGarden, KOTA, NATUREWELL, HEDIMED) on selvitetty vuodesta 2015 lähtien elinympäristön ja terveyden välistä yhteyttä sekä seurantatutkimuksin että altistustutkimuksin. Seurantatutkimuksissa on esimerkiksi kartoitettu kaupungin ja maaseudun asukkaiden mikrobialtistusta keräämällä materiaalia ikääntyneiden suomalaistutkittavien ulko-ovilla käyttämistä kynnysmatoista. Tulosten perusteella kynnysmaton bakteeriyhteisön monimuotoisuus vähentyy rakennetun ympäristön osuuden lisääntyessä (Parajuli ym. 2018). Tiiviisti rakennettujen kaupunkiympäristöjen asukkaat altistuvat siten immuunipuolustuksen kannalta hyödylliselle ympäristön mikrobiomille vähemmän kuin harvaan asutulla maaseudulla elävät. Lisäksi altistuminen monimuotoiselle mikrobiomille on vähäisempää talvella kuin kesällä (Hui ym. 2019a). Vielä julkaisemattomien tulosten perusteella kotipihan kasvillisuus vaikuttaa ihmisen suoliston mikrobiomiin.

Syy-seuraussuhteita selvittävissä altistustutkimuksissa on altistettu vapaaehtoisia tutkittavia biologiselle monimuotoisuudelle. Vastaavanlaisia altistuskokeita ei ole tietääksemme tehty koskaan aikaisemmin. Kokeissa aikuiset tutkittavat ovat hieroneet käsiään metsämaan kaltaiseen, mikrobistoltaan monimuotoiseen maa- ja kasviainekseen. Tulosten perusteella jo lyhytaikainen maa- ja kasviaineksen koskettelu lisää suoliston (Nurminen ym. 2018) ja ihon mikrobiomin monipuolisuutta (Grönroos ym. 2019) sekä vähentää potentiaalisten taudinaiheuttajabakteerien osuutta (Hui ym. 2019b). Lisäksi verestä mitattujen, immuunipuolustusta säätelevien sytokiinien tason havaittiin nousevan elimistön mikrobiomin monipuolisuuden lisääntyessä (Nurminen ym. 2018). Toisaalta erityisesti iholla mikrobiyhteisö näyttää palautuvan nopeasti, mikä viittaa toistuvan tai jatkuvan altistuksen - tai altistumista lisäävien elämäntapamuutosten - tarpeellisuuteen (Grönroos ym. 2019). 
ADELE-tutkimuksen altistuskokeissa on keskitytty mahdollisimman monimuotoisen mikrobikontaktin luomiseen. On kuitenkin vielä epäselvää, onko monimuotoinen mikrobialtistus itsessään tärkeä vai ovatko jotkin monimuotoisen yhteisön yksittäiset lajit tai ryhmät avainasemassa. Tähän mennessä on löydetty useita yksittäisiä mikrobilajeja, joista on tunnistettu mekanismi, jolla ne edistävät immuunipuolustuksen toimintaa (ks. Haahtela 2019). Itsessään monimuotoisuuden merkitystä on tutkittu vähemmän, mutta epäsuoraa näyttöä antavat monet tutkimukset, jotka raportoivat tiettyjä sairauksia sairastavien köyhtyneestä elimistön mikrobistosta verrattuna terveiden henkilöiden mikrobistoon - tosin monissa tutkimuksissa on saatu myös vastakkaisia tuloksia (ks. Karkman ym. 2017). Pelkästään sairaiden ja terveiden mikrobistoa tutkimalla ei kuitenkaan saada tietoa sairauteen johtaneista syistä, sillä mikrobiston muutos voi olla myös sairauden seuraus.

Hiirikokeilla on jo saatu kokeellista näyttöä maan mikrobiston suojaavasta vaikutuksesta. Ottman ym. (2019) vertasivat puhtaissa laboratorio-oloissa eläneitä hiiriä sellaisiin hiiriin, joiden häkkeihin oli lisätty multaa. Maa-ainekseen kosketuksissa olleilla hiirillä oli selvästi erilainen ulosteen ja suolen mikrobisto ja erilaiset immuunijärjestelmän toimintaa kuvaavien proteiinien ja välittäjäaineiden tasot sekä tärkeimpänä, lievemmät allergiaoireet verrattuna puhtaissa oloissa eläneisiin hiiriin. Toisen hiirikokeen perusteella ilman kautta tapahtuva kontakti monimuotoiseen maa-ainekseen näyttää olevan yhteydessä myös ahdistuksen kaltaisen käyttäytymisen vähenemiseen (Liddicoat ym. 2019).

ADELE-tutkimuksen seuraava askel on Pirkanmaalla käynnistynyt PREVALL-koe, jossa tutkitaan monipuolisen mikrobiyhteisön sisältävän maa- ja kasvipohjaisen materiaalin vaikutusta vauvojen allergisoitumisen ehkäisyyn. Tavoitteena on kehittää tapoja atooppisen allergian ja siihen liittyvän IgE-välitteisen allergisen herkistymisen ehkäisyyn. Tutkimus tehdään yhteistyönä Tampereen ja Helsingin yliopistojen lääketieteen tutkijoiden kanssa ja siihen etsitään paraikaa vapaaehtoisia perheitä. Tutkittavat vauvat saavat päivittäiseen käyttöönsä erilaisia maa- ja kasvipohjaista ainesta sisältäviä tuotteita tai vastaavanlaisia lumetuotteita.

\section{Ratkaisuja immuunijärjestelmän häiriöihin}

Altistuminen elinympäristön monimuotoiselle mikrobiomille on erityisen tärkeää varhaisina elinvuosina, sillä immuunijärjestelmä kehittyy pitkälti lapsuudessa. Lisäksi lapsuuden luontokokemukset ja luonnossa liikkuminen vaikuttavat merkittävästi aikuisiän luontosuhteeseen (ks. Rantala \& Puhakka 2019). Uudenlaisia keinoja luontokosketuksen lisäämiseksi ja immuunijärjestelmän häiriöiden ehkäisemiseksi tarvitaan varsinkin kaupunkiympäristössä, jossa luontoalueet ovat kaventuneet ja ohjaamaton vapaa-ajan liikkuminen ulkona on vähentynyt lasten ja nuorten keskuudessa.

Päiväkotien ja koulujen pihat ovat keskeisiä ympäristöjä lasten arkisen luontokontaktin ja mikrobialtistuksen kannalta. ADELE-tutkimuksen kokeessa tuotiin Lahdessa, Tampereella ja Espoossa päiväkotien pihoille kunttaa (sïrrettävää metsämaata), siirtonurmea, istutuslaatikoita ja turveharkkoja. Lapset olivat kosketuksissa vihermateriaaleihin niin ohjatussa toiminnassa kuin vapaan ulkoilun aikana. Selvitimme pihojen vihertämisen vaikutuksia ensinnäkin lasten ihon ja suoliston bakteeriyhteisöön ja immuunipuolustuksen toimintaan sekä toiseksi lasten leikkiin ja liikkumiseen, luontosuhteeseen ja koettuun hyvinvointiin.

Tulosten perusteella luontokosketuksella on tärkeä merkitys lasten kokonaisvaltaiselle hyvinvoinnille (Sinkkonen ym. 2019). Ensimmäisten analyysien perusteella lasten ihon bakteeriyhteisö muuntui ja monipuolistui viherpihan saaneissa päiväkodeissa. Aikaisempien tutkimusten valossa tämänkaltaisten muutosten on todettu parantavan immuunijärjestelmän toimintaa ja säätelyä. Viherpihojen havaittiin myös lisäävän lasten toimintamahdollisuuksia pihoilla; lapset saivat uudenlaisia virikkeitä leikkiin ja heidän liikkumisensa lisääntyi ja monipuolistui. Moniaistiset luontokokemukset voivat vahvistaa lasten luontosuhdetta ja ympäristövastuullisuutta. Viherpihat vaikuttivat myönteisesti sekä lasten että aikuisten mielialaan, jaksamiseen ja motivaatioon päiväkodeissa (Puhakka ym. 2019). Vastaavanlaisia 
myönteisiä vaikutuksia lasten hyvinvointiin, fyysiseen aktiivisuuteen, keskittymiskykyyn ja oppimiseen on havaittu useissa kansainvälisissä tutkimuksissa (ks. Bell \& Dyment 2008).

Tutkimuksessa saatavaa tietoa voidaan hyödyntää paitsi päiväkotien ja koulujen, myös vanhustentalojen ja muiden julkisten piha- ja puistoalueiden suunnittelussa ja rakentamisessa. Pihoilla suositellaan käytettävän viherrakennusmateriaaleja, joissa on runsas ja monimuotoinen mikrobiyhteisö sekä hyvä kulutuskestävyys. Kovan kulutuksen vuoksi suositellaan päiväkotien ja koulujen pihojen jakamista vyöhykkeisiin, jolloin tontin ja raja-aidan suojaan voidaan luoda metsämäistä ympäristöä ja lähinnä rakennusta sijoitetaan perinteiset leikkialueet. Näiden vyöhykkeiden väliin sijoittuu metsän karikekerrokseen ja uudenlaisiin pihamateriaaleihin perustuva vapaan leikin alue. Käyttämällä vyöhykkeistä pihasuunnittelun mallia voidaan lisätä luontokosketuksen paikkojen määrää, saadaan materiaalit kestämään kulutusta tarkoituksenmukaisella tavalla ja helpotetaan pihan kunnossapitoa (Sinkkonen $y m$. 2019). Olemme kehittäneet tavanomaista luontoaltistusta korvaavia, biologisesti monimuotoisia viherrakennusmateriaaleja, kuten monipuolisen mikrobiyhteisön sisältävää leikkihiekkaa, ja tutkineet sille altistumisen vaikutuksia lasten elimistön mikrobiomiin ja immuunipuolustukseen. Mikrobiyhteisöltään metsänkaltaisten puutarha- ja maisemointimateriaalien kehittämisessä hyödynnetään maa- ja metsätalouden sivuainevirtoja. Luontopohjaisten ratkaisujen tutkimusryhmän kehittämiä uusia viherrakennusmateriaaleja ja suunnitteluohjeistusta testataan käytännössä päiväkotipihoilla Espoossa ja Lahdessa.

Tutkimustuloksia voidaan hyödyntää kehitettäessä uusia kuluttajatuotteita mikrobialtistuksen lisäämiseksi niin ulko- kuin sisätiloissa. Suomessa, Iso-Britanniassa ja Saksassa tehdyn laajan markkinatutkimuksen perusteella suuri osa kuluttajista on kiinnostunut uudenlaisista immuunijärjestelmän häiriöitä ehkäisevistä tuotteista. Erityisesti tieteellinen näyttö tuotteen hyödyistä vakuuttaisi kuluttajat kokeilemaan uutta tuotetta (Puhakka ym. 2019). Tämänkaltaisten radikaalien innovaatioiden täytyy kuitenkin olla sellaisessa muodossa, että kuluttajat voivat ne helposti hyväksyä ja omaksua käyttöönsä. Kuluttajien suhtautuminen on todennäköisesti myönteisempää, kun terveyttä edistäviä ominaisuuksia liitetään heille ennestään tuttuihin tuotteisiin sen sijaan, että kehitettäisiin käyttötarkoitukseltaan ja -ominaisuuksiltaan aivan uudenlaisia tuotteita. Kuluttajat muodostavat erilaisia segmenttejä, joista osa voidaan tunnistaa kaupallisten terveyttä edistävien innovaatioiden potentiaalisiksi kohderyhmiksi (Puhakka ym. 2018).

\section{Lopuksi}

Kaupungistuneissa yhteiskunnissa tarvitaan kaupallisten ratkaisujen lisäksi laajempia yhteiskunnallisia muutoksia ihmisen terveyden kannalta hyödyllisten luontokontaktien ylläpitämiseksi ja lisäämiseksi. Esimerkiksi päiväkotien ja koulujen pihaympäristöjen suunnittelukäytäntöjen uudistaminen voidaan nähdä alkuna laajemmalle muutokselle; viherrakenteen merkitys on nostettu keskeisesti esille hyvään rakentamistapaan ohjaavan RT-kortiston hiljattain uusitussa päiväkotien ja koulujen ulkotilojen suunnittelua koskevassa ohjekortissa. Suuremmassa mittakaavassa tarvitaan ajattelutapojen muutosta myös muussa rakentamisessa ja kaupunkisuunnittelussa sekä ohjausta ja kannustusta ihmisten elintavan muutokseen luonnonläheisemmäksi. Joukko lääkäreitä ja muita asiantuntijoita onkin ehdottanut Luontoaskel-hanketta, jonka tavoitteita olisivat muun muassa kansalaisten luontoyhteyden vahvistaminen, luonnon liittäminen lasten ja vanhusten hoitoon sekä kansansairauksien ehkäiseminen (Haahtela ym. 2017). Kaupunkien lähiluonnon sällyttäminen on erityisen tärkeää lapsille ja vanhuksille, joilla on usein muita väestöryhmiä heikommat mahdollisuudet liikkua kauempana sijaitseviin luontokohteisiin. Yhteiskunnassa tulisi korostaa myös erilaisten luontoympäristöjen saavutettavuutta ja luonnossa liikkumisen taitoihin opastamista niin päiväkodeissa, kouluissa kuin harrastustoiminnassa (Rantala \& Puhakka 2019).

Aikaisemmat kotimaiset ja kansainväliset tutkimukset ovat osoittaneet asuinympäristön keskeisen merkityksen ihmisen elimistön mikrobiyhteisön kannalta. ADELE-tutkimuksen 
altistuskokeissa on myös havaittu lyhytaikaisen maa- ja kasviainekselle altistumisen vaikuttavan myönteisesti elimistön mikrobiomin monipuolisuuteen ja immuunipuolustusta säätelevien sytokiinien tasoon. Epäselvää kuitenkin on, voidaanko vastaavanlaisia hyötyjä saada luonnossa tapahtuvan suhteellisen lyhytkestoisen, mutta säännöllisesti toistuvan virkistäytymisen kautta. Luontopohjaisten ratkaisujen tutkimusryhmän hiljattain alkaneissa tutkimuksissa selvitetään tavanomaisen luonnon virkistyskäytön - esimerkiksi retkeilyn, mökkeilyn ja kotiviljelyn - vaikutuksia ihmisen elimistön mikrobiomiin ja immuunipuolustuksen toimintaan. Tutkimuksissa pyritään myös selvittämään, eroavatko perinteisemmät luontoaktiviteetit moderneista, digitaalista teknologiaa hyödyntävistä harrastuksista ja voidaanko esimerkiksi pelien avulla houkutella teini-ikäisiä nuoria liikkumaan luonnossa. Tutkimustuloksia voidaan hyödyntää niin luontomatkailun kehittämisessä kuin ennaltaehkäisevien terveydenhuollon palvelujen uudistamisessa. Tutkimukset ja niiden pohjalta kehitetyt innovaatiot avaavat uudenlaisia mahdollisuuksia immuunijärjestelmän häiriöiden ehkäisemiseksi.

\section{Lähteet}

Aerts, R., Honnay, O. \& Van Nieuwenhuyse, A. (2018) Biodiversity and human health: mechanisms and evidence of the positive health effects of diversity in nature and green spaces. British Medical Bulletin 127 5-22. https://doi.org/10.1093/bmb/ldy021

Bell, A.C. \& Dyment, J.E. (2008) Grounds for health: the intersection of green school grounds and healthpromoting schools. Environmental Education Research 14 77-90. https://doi.org/10.1080/13504620701843426

Ege, M.J., Mayer, M., Schwaiger, K., Mattes, J., Pershagen, G, van Hage, M., Scheynius, A., Bauer, J. \& von Mutius, E. (2012) Environmental bacteria and childhood asthma. Allergy - European Journal of Allergy Clinical Immunology 67 1565-1571. https://doi.org/10.1111/all.12028

Grönroos, M., Parajuli, A., Laitinen, O.H., Roslund, M.I., Vari, H.K., Hyöty, H., Puhakka, R. \& Sinkkonen, A. (2019) Short-term direct contact with soil and plant materials leads to an immediate increase in the diversity of skin microbiota. MicrobiologyOpen 8(3) e645. https://doi.org/10.1002/mbo3.645

Haahtela, T., Holgate, S., Pawankar, R., Akdis, C.A., Benjaponpitak, S., Caraballo, L., Demain, J., Portnoy, J., von Hertzen, L. and WAO Special Committee on Climate Change and Biodiversity (2013) The biodiversity hypothesis and allergic disease: world allergy organization position statement. World Allergy Organization Journal 6 3. http://www.waojournal.org/content/6/1/3

Haahtela, T., Valovirta, E., Hannuksela, M., von Hertzen, L., Jantunen, J., Kauppi, P., Ketola, T., Laatikainen, T., Lindström, I., Mäkinen-Kiljunen, S., Linna, M., Pajunen, S., Pelkonen, A., Petman, L., Puolanne, M., Repo, I., Saarinen, K., Savolainen, J., Tommila, E., Vasankari, T. \& Mäkelä, M.J. (2015) Kansallinen allergiaohjelma 2008-2018 puolivälissä - suunnanmuutos tuo tuloksia. Suomen Lääkärilehti 35 2165-2172.

Haahtela, T., Hanski, I., von Hertzen, L., Jousilahti, P., Laatikainen, T., Mäkelä, M., Puska, P., Reijula, K., Saarinen, K., Vartiainen, E., Vasankari, T. \& Virtanen, S. (2017) Luontoaskel tarttumattomien tulehdustautien torjumiseksi. Duodecim 133(1) 19-26.

Haahtela, T. (2019) A biodiversity hypothesis. Allergy 74 1445-1456. https://doi.org/10.1111/all.13763

Hanski, I., von Hertzen, L., Fyhrqvist, N., Koskinen, K., Torppa, K., Laatikainen, T., Karisola, P., Auvinen, P., Paulin, L., Mäkelä, M.J., Vartiainen, E., Kosunen, T.U., Alenius, H. \& Haahtela, T. (2012) Environmental biodiversity, human microbiota, and allergy are interrelated. PNAS 109 8334-8339. https://doi. org/10.1073/pnas.1205624109

Hui, N., Parajuli, A., Puhakka, R., Grönroos, M., Roslund, M.I., Vari, H.K., Selonen, V.A.O., Yan, G., Siter, N., Nurminen, N., Oikarinen, S., Laitinen, O.H., Rajaniemi, J., Hyöty, H. \& Sinkkonen, A. (2019a) Temporal variation in indoor transfer of dirt-associated environmental bacterial in agricultural and urban areas. Environment International 132 105069. https://doi.org/10.1016/j.envint.2019.105069

Hui, N., Grönroos, M., Roslund, M.I., Parajuli, A., Vari, H.K., Soininen, L., Laitinen, O.H., Sinkkonen, A. and the ADELE research group (2019b) Diverse environmental microbiota as a tool to augment biodiversity in urban landscaping materials. Frontiers in Microbiology 10 536. https://doi.org/10.3389/fmicb.2019.00536

Jäppinen, J-P., Tyrväinen, L., Reinikainen, M. \& Ojala, A. (2014) Luonto lähelle ja terveydeksi. Ekosysteemipalvelut ja ibmisen terveys Argumenta-hank.keen (2013-2014) tulokset ja toimenpidesuositukset. Suomen ympäristökeskuksen raportteja 35. http://hdl.handle.net/10138/153461

Karkman, A., Lehtimäki, J. \& Ruokolainen, L. (2017) The ecology of human microbiota: dynamics and diversity in health and disease. Annals of the New York. Academy of Sciences 1399, 78-92.

Keniger, L., Gaston, K., Irvine, K.N. \& Fuller, R. (2013) What are the benefits of interacting with nature? International Journal of Environmental Research and Public Health 10 913-935. https://doi.org/10.3390/ ijerph10030913 
Konu, H., Tyrväinen, L., Pesonen, J., Tuulentie, S., Pasanen, K. \& Tuohino, A. (2017) Uutta liiketoimintaa luontomatkailun ja virkistyskäytön ympärille - kirjallisuuskatsaus. Valtioneuvoston selvitys- ja tutkimustoiminnan julkaisusarja 45/2017. http://valtioneuvosto.fi/documents/10616/3866814/45_VIRKEIN_.pdf/ eaaab34e-f831-4623-a915-f91d971 e6b46?version=1.0

Liddicoat, C., Sydnor, H., Cando-Dumancela, C., Dresken, R., Liu, J., Gellie, N.J.C., Mills, J.G., Young, J.M., Weyrich, L.S., Hutchinson, M.R., Weinstein, P. \& Breed, M.F. (2019) Naturally-diverse airborne environmental microbial exposures modulate the gut microbiome and may provide anxiolytic benefits in mice. Science of The Total Environment, published online. https://doi.org/10.1016/j.scitotenv.2019.134684

Nurminen, N., Lin, J., Grönroos, M., Puhakka, R., Kramna, L., Vari, H.K., Viskari, H., Oikarinen, S., Roslund, M., Parajuli, A., Tyni, I., Cinek, O., Laitinen, O.H., Hyöty, H. \& Sinkkonen, A. (2018) Nature-derived microbiota exposure as a novel immunomodulatory approach. Future Microbiology 13(7) 737-744. https:// doi.org/10.2217/fmb-2017-0286

Ottman, N., Ruokolainen, L., Suomalainen, A., Sinkko, H., Karisola, P., Lehtimäki, J., Lehto, M., Hanski, I., Alenius, H. \& Fyhrqvist, N. (2019) Soil exposure modifies the gut microbiota and supports immune tolerance in a mouse model. Journal of Allergy and Clinical Immunology 143(3) 1198-1206. https://doi. org/10.1016/j.jaci.2018.06.024

Parajuli, A., Grönroos, M., Kauppi, S., Płociniczak, T., Roslund, M.I., Galitskaya, P., Laitinen, O.H., Hyöty, H., Jumpponen, A., Strömmer, R., Romantschuk, M. \& Sinkkonen, A. (2017) The abundance of healthassociated bacteria is altered in PAH polluted soils - Implications for health in urban areas? PLOS One 12(11) e0187852. https://doi.org/10.1371/journal.pone.0187852

Parajuli, A., Grönroos, M., Siter, N., Puhakka, R., Vari, H.K., Roslund, M.I., Jumpponen, A., Nurminen, N., Laitinen, O.H., Hyöty, H., Rajaniemi, J. \& Sinkkonen, A. (2018) Urbanization reduces transfer of diverse environmental microbiota indoors. Frontiers in Microbiology 9 84. https://doi.org/10.3389/fmicb.2018.00084

Puhakka, R., Valve, R. \& Sinkkonen, A. (2018) Older consumers' perceptions of functional foods and nonedible health-enhancing innovations. International Journal of Consumer Studies 42(1) 111-119. https://doi. org/10.1111/ijcs.12400

Puhakka, R., Ollila, S., Valve, R. \& Sinkkonen, A. (2019) Consumer trust in a health-enhancing innovation - comparisons between Finland, Germany and the United Kingdom. Journal of International Consumer Marketing 31(2) 162-176. https:// doi.org/10.1080/08961530.2018.1498757

Puhakka, R., Rantala, O., Roslund, M.I., Rajaniemi, J., Laitinen, O.H., Sinkkonen, A. \& the ADELE research group (2019) Greening of daycare yards with biodiverse materials affords well-being, play and environmental relationships. International Journal of Environmental Research and Public Health 16(16) 2948. https://doi.org/ 10.3390/ijerph16162948

Rantala, O. \& Puhakka, R. (2019) Engaging with nature: nature affords well-being for families and young people in Finland. Children's Geographies, published online. https://doi.org/10.1080/14733285.2019.1685076

Rieder, R., Wisniewski, P.J., Alderman, B.L. \& Campbell, S.C. (2017) Microbes and mental health: a review. Brain, Behavior, and Immunity 66 9-17. https:/ / doi.org/10.1016/j.bbi.2017.01.016

Rook, G.R. (2013) Regulation of the immune system by biodiversity from the natural environment: an ecosystem service essential to health. PNAS 46: 18360-18367.

Roslund, M.I., Grönroos, M., Rantalainen, A-L., Jumpponen, A., Romantschuk, M., Parajuli, A., Hyöty, H., Laitinen, O. \& Sinkkonen, A. (2018) Half-lives of PAHs and temporal microbiota changes in commonly used urban landscaping materials. PeerJ 6, e4508. https://doi.org/10.7717/peerj.4508

Roslund, M.I., Rantala, S., Oikarinen, S., Puhakka, R., Hui, N., Parajuli, A., Laitinen, O.H., Hyöty, H., Rantalainen, A-L., Sinkkonen, A. and the ADELE team (2019) Endocrine disruption and commensal bacteria alteration associated with gaseous and soil PAH contamination among daycare children. Environment International 130 104894. https://doi.org/10.1016/j.envint.2019.06.004

Ruokolainen L., von Hertzen L., Fyhrquist, N., Laatikainen T., Lehtomäki, J., Auvinen, P., Karvonen, A.M., Hyvärinen, A., Tillmann, V., Niemelä, O., Knip, M., Haahtela, T., Pekkanen, J. \& Hanski, I. (2015) Green areas around homes reduce atopic sensitization in children. Allergy - European Journal of Allergy Clinical Immunology 70 195-202. https://doi.org/10.1111/all.12545

Ruokolainen, L., Fyhrqvist, N. \& Haahtela, T. (2016) The rich and the poor: environmental biodiversity protecting from allergy. Current Opinion in Allergy and Clinical Immunology 16(5) 421-426. https://doi. org/10.1097/ACI.0000000000000304

Santaoja, M. (2018) Allergioista uusia näkökulmia ihmisen ja muun luonnon keskinäisriippuvuuteen. Alue ja Ympäristö 47(2) 53-58. https://doi.org/10.30663/ay.74257

Sinkkonen, A., Tahvonen, O., Puhakka, R. \& Roslund, M. (2019) Viherpihalta terveyttä ja hyvinvointia: kohti tervettä aikuisuutta (KOTA) - päiväkodin viherpihan vaikutus lasten kokonaisvaltaiseen hyvinvointiin. Policy brief -artikkeli. Kaupunkitutkimus- ja metropolipolitiikka -tutkimus ja -yhteistyöohjelma. < https:// urbanacademy.fi/ajankohtaistatutkimusta/viherpihalta-terveytta-ja-byvinvointia/>

von Hertzen, L., Hanski, I. \& Haahtela, T. (2011) Natural immunity: biodiversity loss and inflammatory diseases are two global megatrends that might be related. EMBO Reports 12, 1089-1093. https://doi. org/10.1038/embor.2011.195 